\title{
Cooperative Learning Structures (CLS) to Improve Students' Speaking Skill
}

\author{
Rustiyani $^{1}$ \\ 1Universitas Negeri Bengkulu, Bengkulu, Indonesia,prickly13rose@gmail.com
}

\begin{abstract}
In learning a language, we learn the four skills, they are speaking, listening, reading, and writing.One of the important skills that must be mastered by the learners is speaking. Mastering speaking is a need in order to be able to use the language to communicate. One of the methods that attracts many languages teachers' interest in this 21 st century is cooperative learning structure (CLS). Cooperative Learning Structure is instructional use of the small groups so that students work together to maximize their own and each other's learning. Within cooperative situations, every student seeks outcomes that are beneficial to themselves and beneficial to all other group members. In this paper the writer will discuss about speaking skill, the definition of cooperative learning structure, types of cooperative learning, and how the use of cooperative learning can improve students' speaking skill.
\end{abstract}

Keywords: Cooperative Learning, Speaking Skill

\section{INTRODUCTION}

There are four skills that must be mastered by students when they learn English. The four skills are reading, listening, speaking, and writing. Speaking is considered to be the most favorite and challenging. It contains a complex process of constructing meaning and learners are required to produce linguistically and pragmatically correct utterances. People, who are learning English, interested in speaking because it is considered to be the proof to show people of their competence in the language. Therefore, it is needed to build meaningful activities in teaching speaking for students.

\section{Speaking Skill}

Speaking skill is considered as a very important skill to be achieved in learning language. By speaking, people can communicate verbally to convey their meaning, ideas, or feeling. Nunan (2003:81) states that speaking skill is the productive oral skill consisting of producing systematic verbal utterance to convey meaning. Chaney (1998:13) in Wisma defines speaking as the process of building and sharing meaning through the use of verbal and non-verbal symbols, in a variety of context.

It can be concluded that speaking is the way to express meaning, ideas or feeling by using spoken words in a variety of context.

The goal of learning English is to achieve the competency in using the language for communication. Therefore, communicative competence is needed. It can not be separated from speaking. Richard (2006:2) states that communicative competence includes the following aspects of language knowledge:
1. Mastering how to use language in different goals and functions

2. Mastering how to vary the use of language based on setting and the participants (e.g., be aware to the formal and informal situation)

3. Mastering how to produce and understand different types of texts (e.g., narratives, reports, interviews, conversations)

4. Mastering how to maintain communication despite having limitation in one's language knowledge (e.g., through using different kinds of communication strategies)

\section{Cooperative Learning Structures}

Cooperative learning structure is learning strategy that is known by many linguists. The use of CLS in classroom activities implies the new roles for teachers and learners in the classroom. In this case, learners are being active and becoming the centered of the learning activities. Learners must participate in the classroom activities actively. Because in CLS students must work with other students to reach the goal of learning. So they will learn in group work, pair work tasks, etc. Teachers become a facilitator and monitor in the learning process rather than being a model for correct speech. Each member of a team is responsible not only for his/her achievement of learning but also their teammates achievements.

Johnson, Johnson, and Smith in Nasser states that Cooperative learning refers to a teaching technique where students work in groups on a certain activity in order to maximize one another's learning and to achieve certain goals. In CL, students work in small group to help one another in learning academic content. 


\section{Basic Component of Cooperative Learning Structures}

Based on Johnson, Johnson and Smith there are five components of CL:

1.Positive Interdependence

It refers to the idea that students need to work together to reach the goals of learning. In this case, students must be able to get the success of learning. All of them work together to make it comes true. They support each other, share the explanation and the guidance to achieve learning objectives.

2.Individual Accountability

It means that each team member is responsible for his/her fair share to the group's success. It is essential that the group recognize who needs more some help, support, and encouragement in finishing the task. It needs each student in the group to improve a sense of individual responsibility to learn and the other members in the group.

3.Promotive Interaction

It refers to the intercommunication of students in order to assist each other to complete the task and the group's shared aims. Students need to contact verbally with one another on learning tasks. They are also expected to clarify things to each other, teach others, and afford each other with help, support, and encouragement.

4.Interpersonal and Social Skill

It refers to the skills such as allowing constructive feedback, reaching consensus, communication accurately and unambiguously and encouraging every member in the learning process. However, not all students know about these skills. Teacher must explain and practiced it before giving the task to the students.

The teacher is not a person who measures the capacities of the students in terms of the final product, but somebody who act as a friend, coordinator, director, guide, counselor, and facilitator (Cowei et al 1994)

5.Group Processing

It is an essentialt aspect of CL. The group members need to assess their functions and contributions to the success of all tasks. It focuses on positive behaviours and actions rather than on negative ones and involves students thinking about how they learn. Additionally, the teacher may choose to spend time specifically focusing on improving a skill such as speaking. The teacher can then monitor the different groups during the learning activities and accommodate feedback on what has been observed.

\section{RESULT AND DISCUSSION}

\section{Using Cooperative Learning in Teaching Speaking}

In teaching speaking, teacher must be able to engage all students to explore their ability. Cooperative learning is one strategy that can be used to teach speaking. It is considered as the effective strategy to establish their speaking skill. In this way, students are conducted to work in group to be success together in doing the task from the teacher. It is more efficient since the students work in groups to build communication each other. Teacher as a facilitator, monitor, and coach has a role to help students in establishing their communicative competence.

These are five phases of cooperative learning structures:

1.In the "engagement" phase, the teacher "sets the stage" for the activity presented

2.In the "exploration" phase, students work on the "beggining exploration of ideas and information"

3.In the "transformation" phase, this is where the students assemble all of their ideas about the information

4.In the "presentation" phase, the students explain their information to the other students

5.In the "reflection" phase, the students analyzed what they have learned and identify strengths and weaknesses in the learning process that they went through.

In this case, all students are conducted to engage in all activities in the classroom. There is no "I" in learning. All students have responsibility to be active in learning process. They are also motivated by their teammates to reach the goal of learning together.

\section{CONCLUSION}

Cooperative learning structures is one strategy which is considered as the effective way in teaching speaking. The students are motivated to be active in every task that is given by the teacher. Students are responsibility to reach the success of learning for their groups. In this case, teacher as a facilitator, monitor, and coach in learning process. Students centered is practiced here. Therefore, cooperative learning is better to be used to improve students speaking skill.

\section{REFERENCES}

[1] Al-Tamimi. Nasser Omar M. (2014). Effectiveness of Cooperative Learning in Enhancing Speaking Skill and Attitudes towards Learning English. Yemen: Hadhramout University.

[2] Chaney, A.L., and T.L. Burk. (1998). Teaching Oral Communication in Grades $K$-8.Boston: Allyn\&Bacon.

[3] Nunan, David. (2003). Practical Language Teaching. New York: McGraw-Hill.

[4] Nunan, David. (2015). Teaching English to Speakers of Other Language. New York: Routledge.

[5] Richard, Jack C. (2006). Communicative Language Teaching Today. Cambridge: Cambridge University Press. 